NASA/TM-2000-209891, Vol. 115

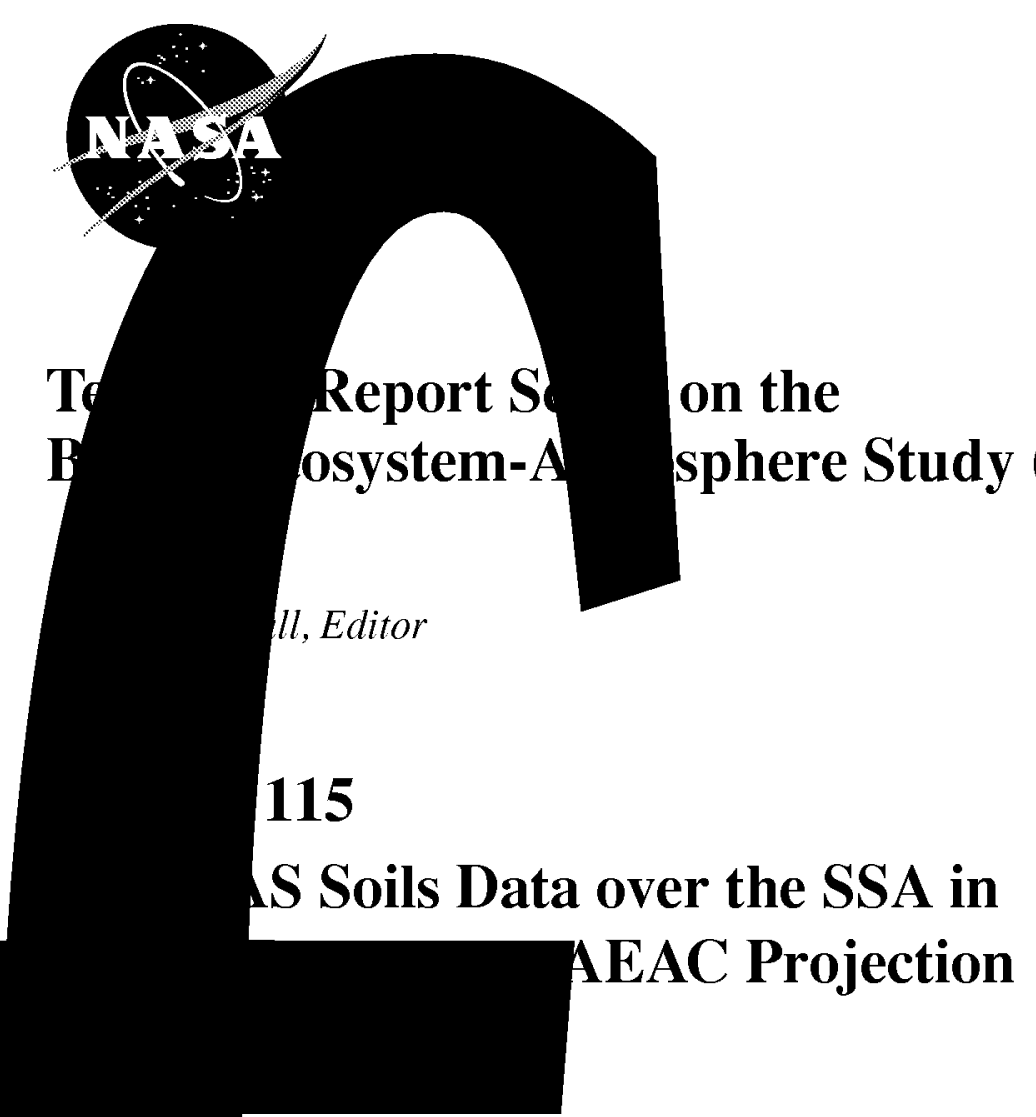

nd H. Rostad

nautics and

stration

ce Flight Center

yland 20771

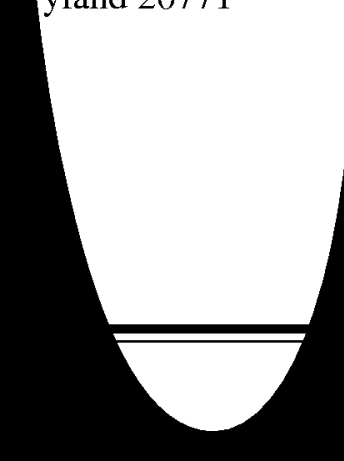


The NASA STI Program Office ... in Profile

Since its founding, NASA has been dedicated to the advancement of aeronautics and space science. The NASA Scientific and Technical Information (STI) Program Office plays a key part in helping NASA maintain this important role.

The NASA STI Program Office is operated by Langley Research Center, the lead center for NASA's scientific and technical information. The NASA STI Program Office provides access to the NASA STI Database, the largest collection of aeronautical and space science STI in the world. The Program Office is also NASA's institutional mechanism for disseminating the results of its research and development activities. These results are published by NASA in the NASA STI Report Series, which includes the following report types:

- TECHNICAL PUBLICATION. Reports of completed research or a major significant phase of research that present the results of NASA programs and include extensive data or theoretical analysis. Includes compilations of significant scientific and technical data and information deemed to be of continuing reference value. NASA's counterpart of peer-reviewed formal professional papers but has less stringent limitations on manuscript length and extent of graphic presentations.

- TECHNICAL MEMORANDUM. Scientific and technical findings that are preliminary or of specialized interest, e.g., quick release reports, working papers, and bibliographies that contain minimal annotation. Does not contain extensive analysis.

- CONTRACTOR REPORT. Scientific and technical findings by NASA-sponsored contractors and grantees.
- CONFERENCE PUBLICATION. Collected papers from scientific and technical conferences, symposia, seminars, or other meetings sponsored or cosponsored by NASA.

- SPECIAL PUBLICATION. Scientific, technical, or historical information from NASA programs, projects, and mission, often concerned with subjects having substantial public interest.

- TECHNICAL TRANSLATION. English-language translations of foreign scientific and technical material pertinent to NASA's mission.

Specialized services that complement the STI Program Office's diverse offerings include creating custom thesauri, building customized databases, organizing and publishing research results ... even providing videos.

For more information about the NASA STI Program Office, see the following:

- Access the NASA STI Program Home Page at http://www.sti.nasa.gov/STI-homepage.html

- E-mail your question via the Internet to help@sti.nasa.gov

- Fax your question to the NASA Access Help Desk at (301) 621-0134

- Telephone the NASA Access Help Desk at (301) 621-0390

- Write to:

NASA Access Help Desk

NASA Center for AeroSpace Information 7121 Standard Drive Hanover, MD 21076-1320 
NASA/TM-2000-209891, Vol. 115

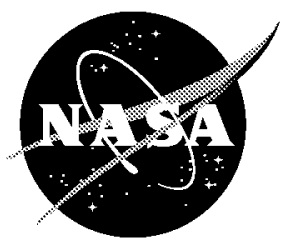

Technical Report Series on the Boreal Ecosystem-Atmosphere Study (BOREAS)

Forrest G. Hall, Editor

\section{Volume 115}

BOREAS Soils Data over the SSA in Raster Format and AEAC Projection

David Knapp, Raytheon ITSS, NASA Goddard Space Flight Center,

Greenbelt, Maryland

Harold Rostad, Agriculture Canada, Ottawa, Ontario, Canada

National Aeronautics and

Space Administration

Goddard Space Flight Center

Greenbelt, Maryland 20771 


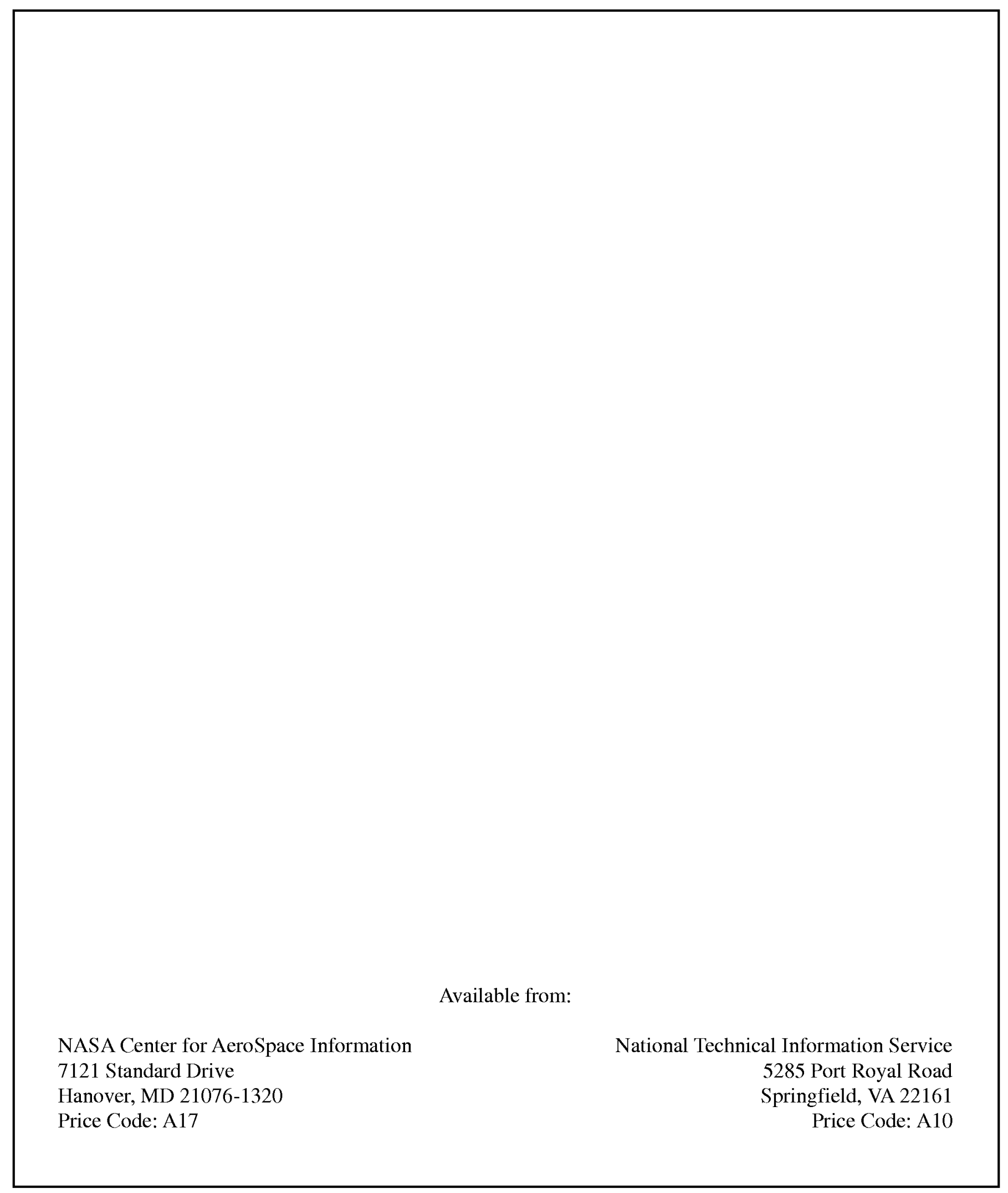




\title{
BOREAS Soils Data over the SSA in Raster Format and AEAC Projection
}

\author{
David Knapp, Harold Rostad
}

\section{Summary}

This data set consists of GIS layers that describe the soils of the BOREAS SSA. The original data were submitted as vector layers that were gridded by BOREAS staff to a 30 -meter pixel size in the AEAC projection. These data layers include the soil code (which relates to the soil name), modifier (which also relates to the soil name), and extent (indicating the extent that this soil exists within the polygon). There are three sets of these layers representing the primary, secondary, and tertiary soil characteristics. Thus, there is a total of nine layers in this data set along with supporting files. The data are stored in binary, image format files.

Note that several files of this data set on the BOREAS CD-ROMs have been compressed using the Gzip program. See Section 8.2 for details.

\section{Table of Contents}

1) Data Set Overview

2) Investigator(s)

3) Theory of Measurements

4) Equipment

5) Data Acquisition Methods

6) Observations

7) Data Description

8) Data Organization

9) Data Manipulations

10) Errors

11) Notes

12) Application of the Data Set

13) Future Modifications and Plans

14) Software

15) Data Access

16) Output Products and Availability

17) References

18) Glossary of Terms

19) List of Acronyms

20) Document Information

\section{Data Set Overview}

\subsection{Data Set Identification \\ BOREAS Soils Data over the SSA in Raster Format and AEAC Projection}

\subsection{Data Set Introduction}

This data set consists of Geographic Information System (GIS) layers that describe the soils of the BOReal Ecosystem-Atmosphere Study (BOREAS) Southern Study Area (SSA). The original data were submitted as vector layers that were gridded by BOREAS staff to a 30-meter pixel size. The pixels contain integer values that link to data tables that indicate the soil name. 


\subsection{Objective/Purpose}

These data are provided as part of the BOREAS Staff Science GIS Data Collection Program, which included the collection of pertinent map data, in both hardcopy and digital form. The objective of this data set is to provide BOREAS investigators with a map of soil types and other soil properties.

Although this data set was received from Agriculture Canada, it does not cover agricultural areas of the BOREAS SSA, only forested areas.

\subsection{Summary of Parameters}

The parameters contained include:

SOIL CODE, MODIFIERS, EXTENT, and soil names for primary, secondary, and tertiary soil units.

\subsection{Discussion}

These data layers include the soil code (which relates to the soil name), modifier (which also relates to the soil name), and extent (indicating the extent that this soil exists within the polygon). There are three sets of these layers representing the primary, secondary, and tertiary soil characteristics. Thus, there is a total of nine layers in this data set along with supporting files. The data are stored in binary, image format files.

\subsection{Related Data Sets}

Agriculture Canada Central Saskatchewan Vector Soils Data

CanSIS Regional Soils Data in Vector Format

BOREAS Regional Soils Data in Raster Format and AEAC Projection

\section{Investigator(s)}

\subsection{Investigator(s) Name and Title} BOREAS Staff Science

\subsection{Title of Investigation}

BOREAS Staff Science GIS Data Collection Program

\subsection{Contact Information}

\section{Contact 1:}

Dr. Harold Rostad

Agriculture Canada

Saskatoon, SK

CANADA S7N 0W0

(306) 975-6305

rostad@digger.usask.ca

\section{Contact 2:}

David Knapp

Raytheon ITSS

NASA GSFC

Code 923

Greenbelt, MD 20771

(301) 286-1424

David.Knapp@gsfc.nasa.gov 


\section{Theory of Measurements}

Unknown.

\section{Equipment}

4.1 Sensor/Instrument Description

Unknown.

4.1.1 Collection Environment

Unknown.

4.1.2 Source/Platform

Unknown.

4.1.3 Source/Platform Mission Objectives

Unknown.

4.1.4 Key Variables

Unknown.

4.1.5 Principles of Operation

Unknown.

4.1.6 Sensor/Instrument Measurement Geometry

Unknown.

4.1.7 Manufacturer of Sensor/Instrument

Unknown.

\subsection{Calibration}

Unknown.

\subsubsection{Specifications}

Unknown.

4.2.1.1 Tolerance

Unknown.

4.2.2 Frequency of Calibration

Unknown.

\subsubsection{Other Calibration Information}

Unknown.

\section{Data Acquisition Methods}

These data were acquired in ARC/INFO EXPORT format as vector coverages. The Soil Names file and Soil Layer file are standard files that provide soil attributes for the province of Saskatchewan. The soil code for each polygon can be linked to the corresponding soil number attribute in the Soil Names file. 


\section{Observations}

\subsection{Data Notes \\ Unknown. \\ 6.2 Field Notes \\ Unknown.}

\section{Data Description}

\subsection{Spatial Characteristics}

\subsubsection{Spatial Coverage}

These data cover the Southern Study Area (SSA) and a buffer area around it. The locations of the outside corners of the corner pixels are:

\begin{tabular}{|c|c|c|c|c|}
\hline & BOREAS & BOREAS & & \\
\hline Point & $\mathrm{X} \quad(\mathrm{km})$ & $Y \quad(k m)$ & Longitude & Latitude \\
\hline Northwest & 303.000 & 399.990 & $106.31380 \mathrm{~W}$ & $54.50245 \mathrm{~N}$ \\
\hline Northeast & 464.610 & 399.990 & $103.82894 \mathrm{~W}$ & $54.37908 \mathrm{~N}$ \\
\hline Southeast & 464.610 & 282.000 & $104.01113 \mathrm{~W}$ & $53.32543 \mathrm{~N}$ \\
\hline Southwest & 303.000 & 282.000 & $106.43333 \mathrm{w}$ & $53.44574 \mathrm{~N}$ \\
\hline
\end{tabular}

\subsubsection{Spatial Coverage Map}

Not available.

\subsubsection{Spatial Resolution}

These data were gridded to a cell size of 30 meters in the $\mathrm{X}$ and $\mathrm{Y}$ directions.

\subsubsection{Projection}

The established BOREAS grid system is based on the ellipsoidal version of the Albers Equal-Area Conic (AEAC) projection as defined within the North American Datum of 1983 (NAD83). The origin of the grid is at $111^{\circ} \mathrm{W}, 51^{\circ} \mathrm{N}$, and the standard parallels are set to $52.5^{\circ} \mathrm{N}$ and $58.5^{\circ} \mathrm{N}$ as prescribed in "Map Projections - A Working Manual," USGS Professional Paper 1395, John P. Snyder, 1987. All of the projection equations used to calculate the BOREAS grid coordinates were taken from this manual.

\subsubsection{Grid Description}

The gridded layers are projected into the AEAC projection described in Section 7.1.4 at a resolution of 30 meters per pixel (grid cell) in both the $\mathrm{X}$ and $\mathrm{Y}$ directions.

\subsection{Temporal Characteristics}

\subsubsection{Temporal Coverage}

The time at which these soils were mapped could not be determined. They may have originally been mapped in the early 1980s, but the data have been updated and edited by Agriculture Canada based on new information since that time.

\subsubsection{Temporal Coverage Map}

Not available. 


\title{
7.2.3 Temporal Resolution Unknown.
}

\subsection{Data Characteristics}

\author{
7.3.1 Parameter/Variable \\ SOIL CODE 1 \\ SOIL CODE 2 \\ SOIL CODE 3 \\ MODIFIER SOIL 1 \\ MODIFIER SOIL 2 \\ MODIFIER SOIL 3 \\ EXTENT OF SOIL 1 \\ EXTENT OF SOIL 2 \\ EXTENT OF SOIL 3
}

\subsubsection{Variable Description/Definition}

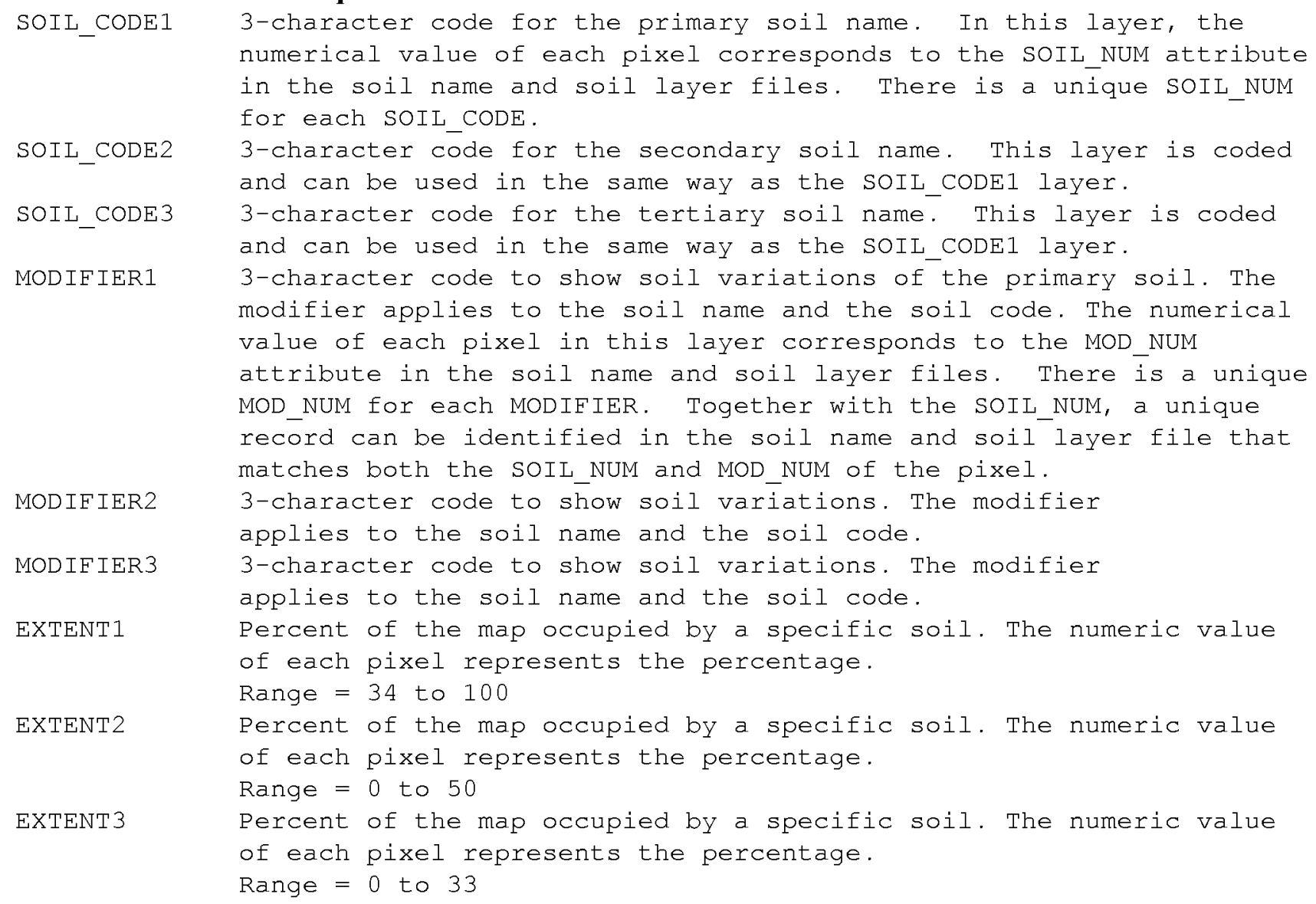

The three SOIL_CODE and three MODIFIER layer attributes are associated with soil names. As explained above, they can be linked to the SOIL_NUM and MOD_NUM values in the soil name and soil layer files. Please refer to section 8.2.1 to decode this information in the soil names file. The items in the soil names file are listed in the following order:

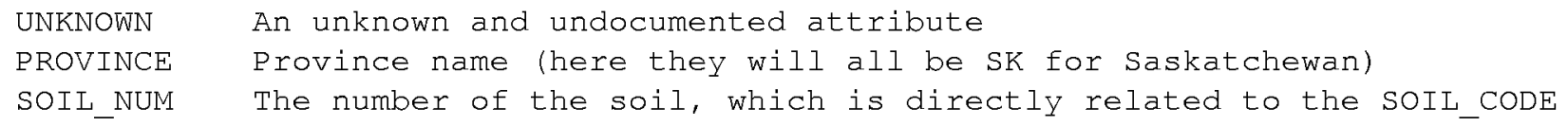




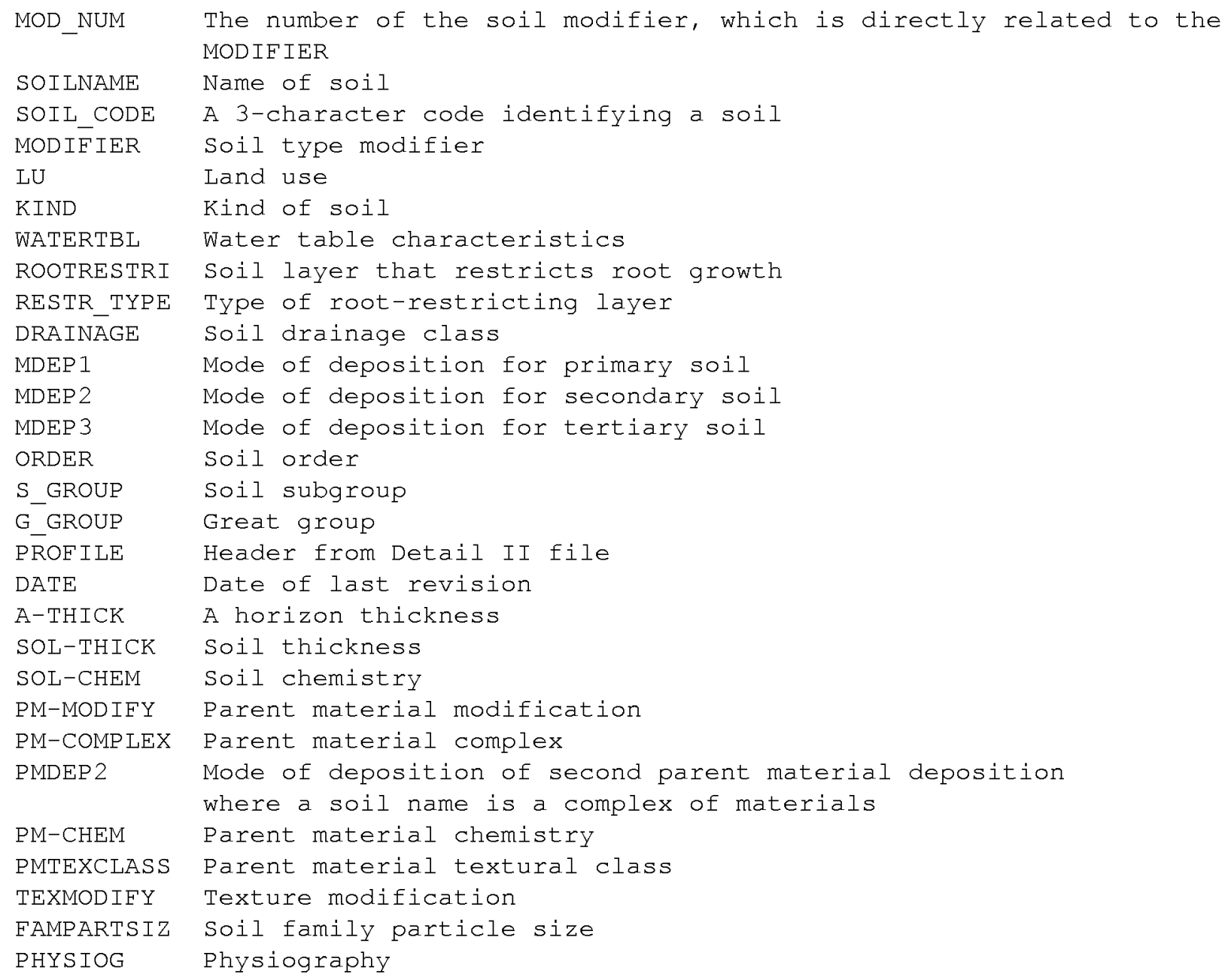

A subset of the Soil Layer file is also included with this data set. This subset includes the layer information for the soils that occur in the SSA. The information in the Soil Names file can be linked to the Soil Layer file with the SOIL_NUM and/or SOIL_CODE. The Soil Layer file provides information about the soil strata for a particular soil name. The attributes in the Soil Layer file include:

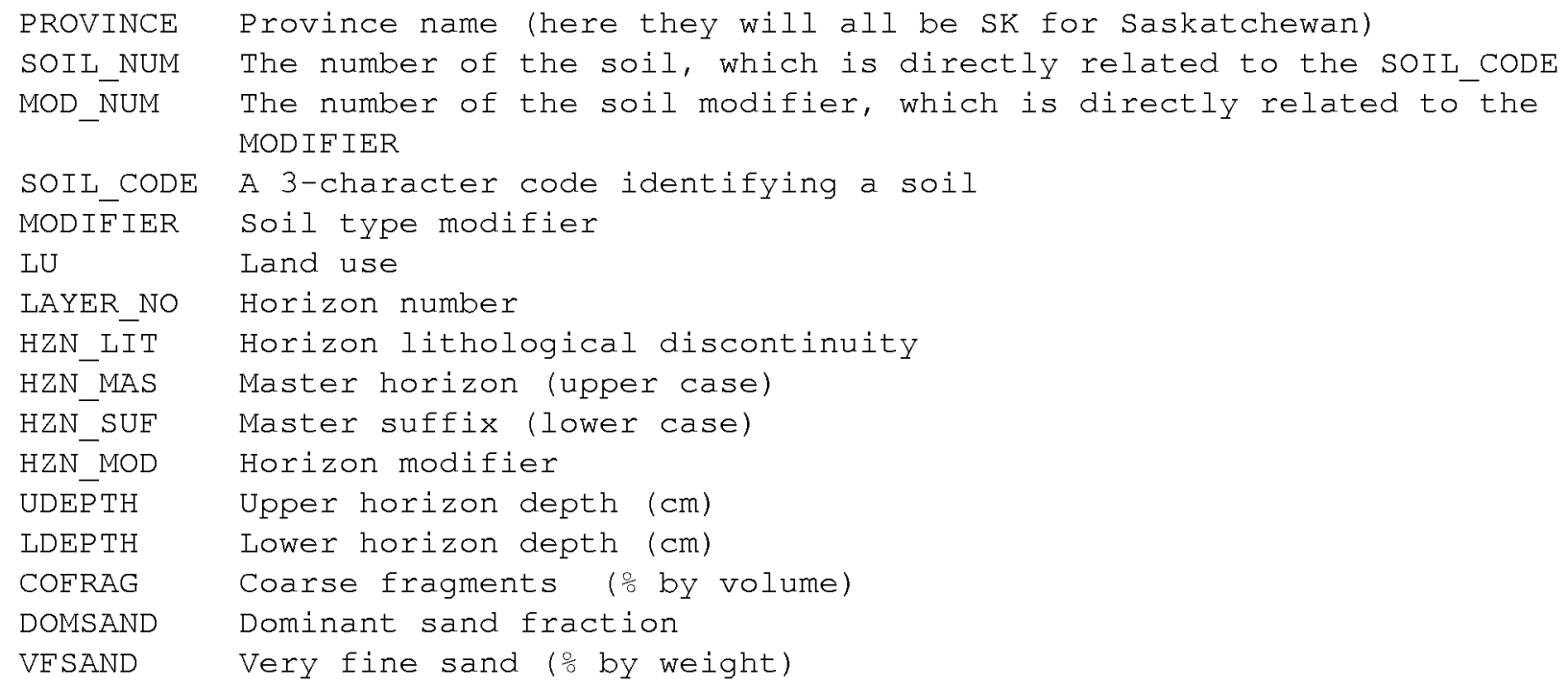




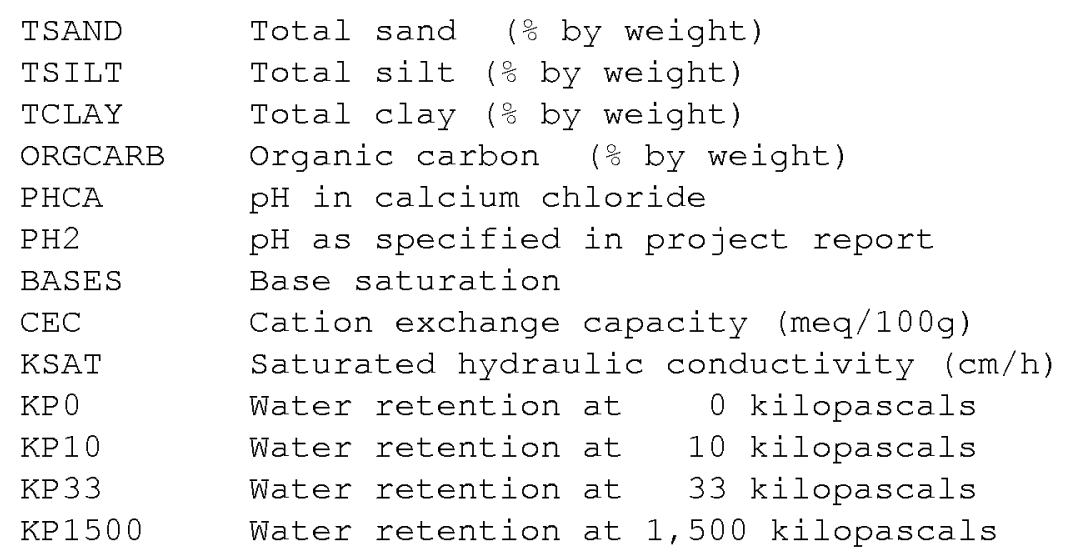

(Water retention units are $\%$ by volume corrected for coarse fragment content.)

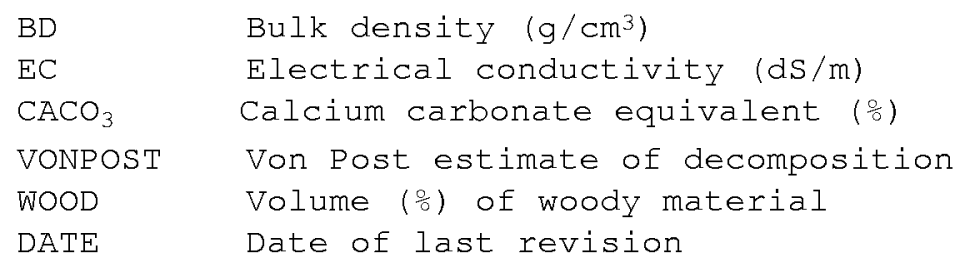

\subsubsection{Unit of Measurement}

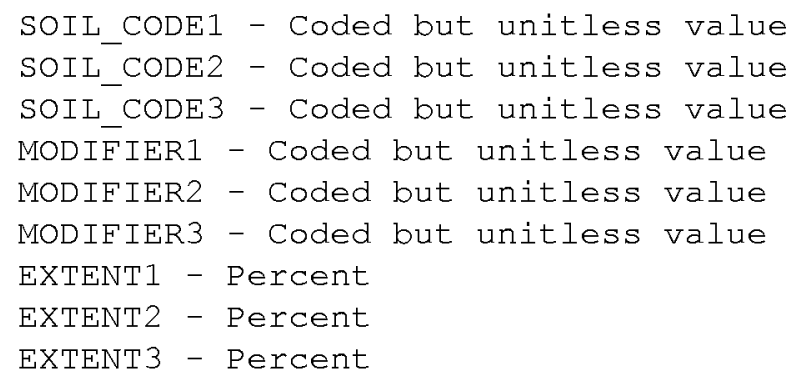

\subsubsection{Data Source}

The data from which this data set was derived were acquired in ARC/INFO format from:

Dr. Harold P.W. Rostad, Unit Head

Agriculture Canada-Research-CLBRR/LRD

Saskatchewan Land Resource Unit

Room 5C26 Agriculture Building

c/o The Soil Science Department

University of Saskatchewan Campus

\section{Saskatoon, SK CANADA S7N 0W0}

\subsubsection{Data Range}

See Section 7.3.2.

\subsection{Sample Data Record}

The following are sample data records of the Saskatchewan Soil Names File:

$\mathrm{T}, \mathrm{SK}, 2,1, \mathrm{ARDILL} \mathrm{O} . \mathrm{B}, \mathrm{ADA}, \mathrm{A}, \mathrm{M}, \mathrm{NO}, 0,-, \mathrm{W}, \mathrm{TILL},-,-, \mathrm{CH}, \mathrm{O}, \mathrm{B}, 19901213, \mathrm{~L} 20,40, \mathrm{AN}, \mathrm{CRET}$, $-,-, \mathrm{VC}, \mathrm{CL},-, \mathrm{FL},-\mathrm{T}, \mathrm{SK}, 2,41, \mathrm{ARDILL} O \mathrm{O}, \mathrm{ADA}, \mathrm{R}, \mathrm{A}, \mathrm{M}, \mathrm{NO}, 4, \mathrm{LI}, \mathrm{W}, \mathrm{TILL}, \mathrm{RESD},-, \mathrm{CH}, \mathrm{O}, \mathrm{B}$, , $19901213, \mathrm{~L} 20,40, \mathrm{AN}, \mathrm{CRET},-,-, \mathrm{VC}, \mathrm{CL},-, \mathrm{FL},-$ 
The following are sample data records of the Saskatchewan Soil Layer File:

$\mathrm{SK}, 2,1, \mathrm{ADA}, \mathrm{A}, 1, \mathrm{~A}, \mathrm{P}, 0,0,13,0, \mathrm{VF}, 12,38,36,26,1.7,6.8,7.0,100,22,3.290,47,-9,34$, $20,1.40,1,0,-9,-9,19910111 \mathrm{SK}, 2,1, \mathrm{ADA}, \mathrm{A}, 2, \mathrm{~B}, \mathrm{~m}, 13,40,0, \mathrm{VF}, 13,35,32,33,1.0,7.2$, $7.4,100,24,2.350,47,-9,35,21,1.40,1,0,-9,-9,19910111$

\section{Data Organization}

\subsection{Data Granularity}

The smallest unit of data for this data set is the entire data set on tape.

\subsection{Data Format(s)}

\subsubsection{Uncompressed Data Files}

This data set consists of the following files:

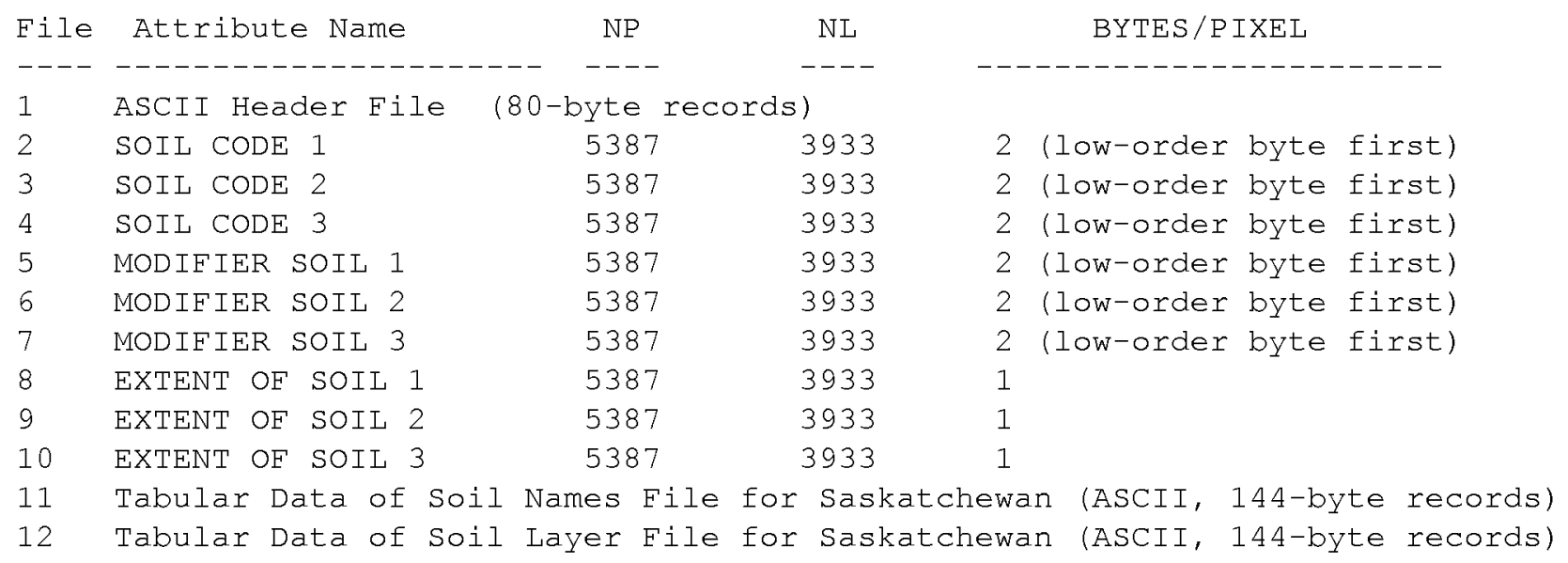

The following information, which is needed to decode the Soil Names file, was extracted (with modifications) from an information sheet from the Canadian Soil Information System (CanSIS):

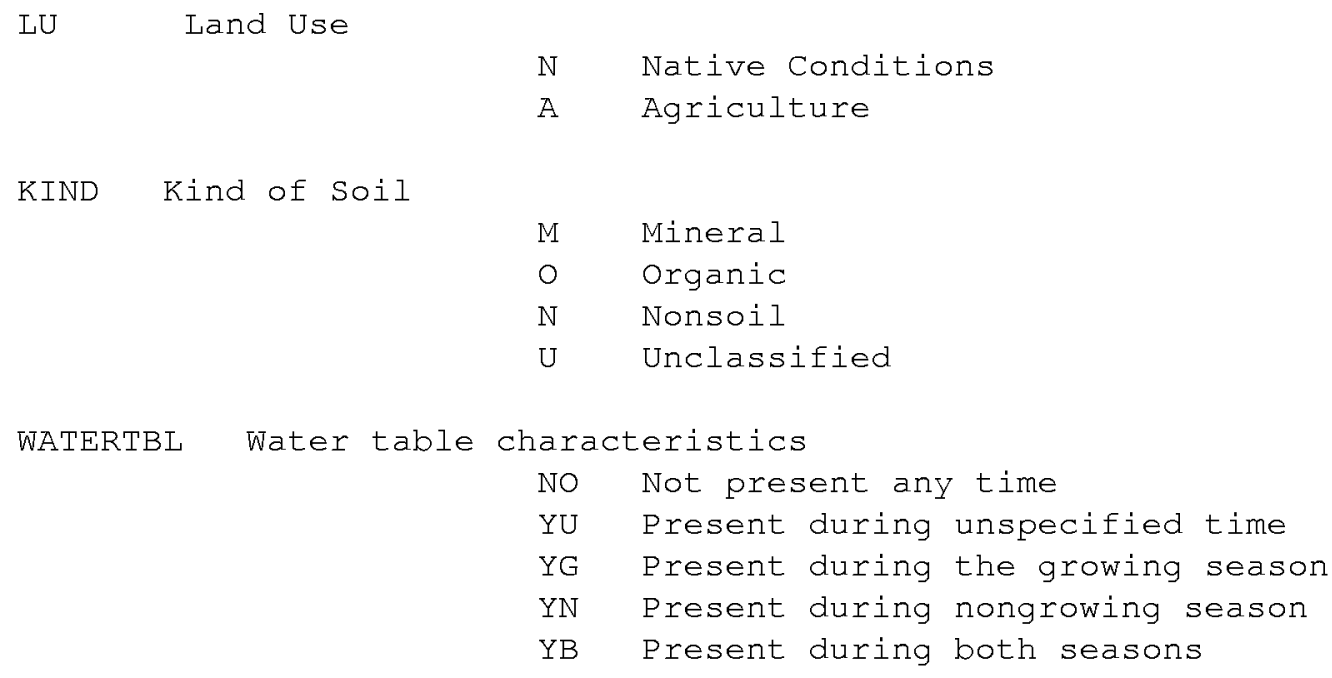




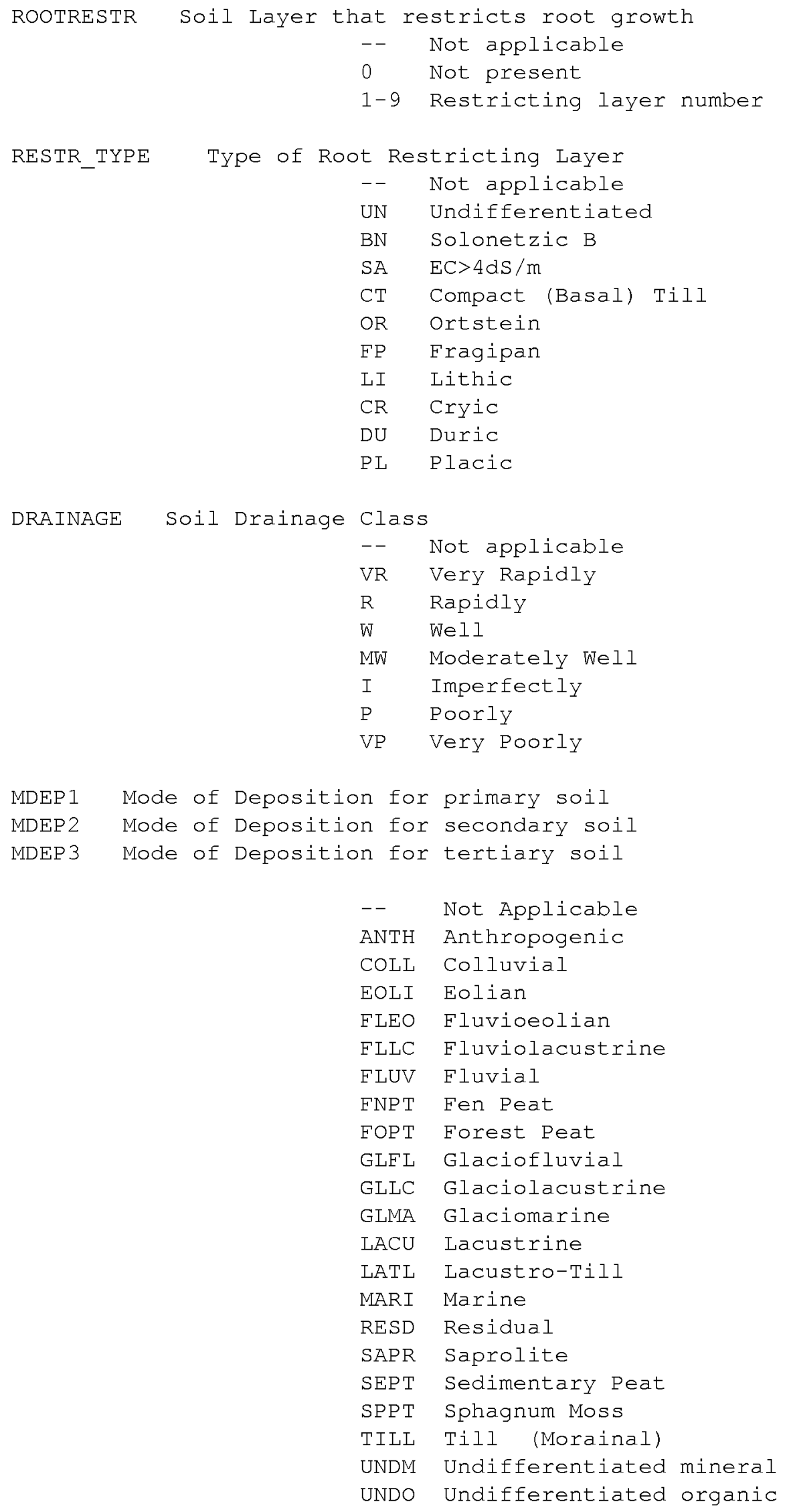


ORDER SOIl Order

$\begin{array}{ll}-- & \text { Not Applicable } \\ \text { BR } & \text { Brunisolic } \\ \text { CH } & \text { Chernozemic } \\ \text { CY } & \text { Cryosolic } \\ \text { GL } & \text { Gleysolic } \\ \text { LU } & \text { Luvisolic } \\ \text { OR } & \text { Organic } \\ \text { PZ } & \text { Podzolic } \\ \text { RG } & \text { Regosolic } \\ \text { SZ } & \text { Solonetzic }\end{array}$

Soil Subgroup and Great Group. Characters before the dot (.) go into the S_GROUP (soil subgroup) field. Characters after the dot go into the G_GROUP (soil great group) field.

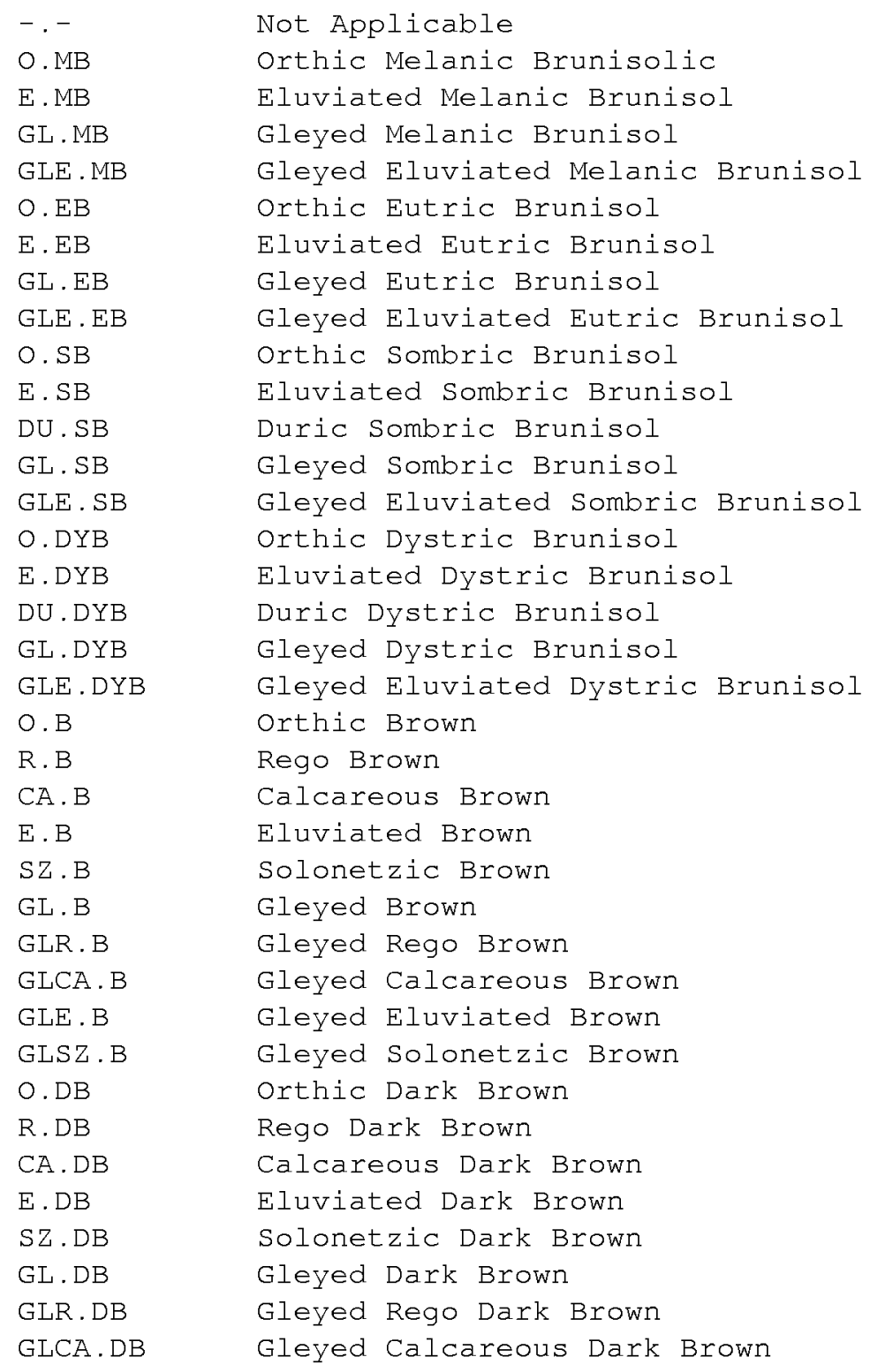




\begin{tabular}{|c|c|}
\hline GLE . DB & Gleyed Eluviated Dark Brown \\
\hline GLSZ . DB & Gleyed Solonetzic Dark Brown \\
\hline $\mathrm{O} . \mathrm{BL}$ & Orthic Black \\
\hline R.BL & Rego Black \\
\hline CA.BL & Calcareous Black \\
\hline E.BL & Eluviated Black \\
\hline SZ.BL & Solonetzic Black \\
\hline GL . BL & Gleyed Black \\
\hline GLR. BL & Gleyed Rego Black \\
\hline GLCA. BL & Gleyed Calcareous Black \\
\hline GLE . BL & Gleyed Eluviated Black \\
\hline GLSZ . BL & Gleyed Solonetzic Black \\
\hline$O . D G$ & Orthic Dark Gray \\
\hline R.DG & Rego Dark Gray \\
\hline CA. DG & Calcareous Dark \\
\hline SZ . DG & Solonetzic Dark Gray \\
\hline GL . DG & Gleyed Dark Gray \\
\hline GLR. DG & Gleyed Rego Dark Gray \\
\hline GLCA.DG & Gleyed Calcareous Dark Gray \\
\hline GLSZ . DG & Gleyed Solonetzic Dark Gray \\
\hline O. TC & Orthic Turbic Cryosol \\
\hline BR. TC & Brunisolic Turbic Cryosol \\
\hline R.TC & Rego Turbic Cryosol \\
\hline GL . TC & Gleysolic Turbic Cryosol \\
\hline O. SC & Orthic Static Cryosol \\
\hline BR.SC & Brunisolic Static Cryosol \\
\hline R.SC & Regosolic Static Cryosol \\
\hline GL . SC & Gleysolic Static Cryosol \\
\hline FI.OC & Fibric Organic Cryosol \\
\hline $\mathrm{ME} . \mathrm{OC}$ & Mesic Organic Cryosol \\
\hline $\mathrm{HU} . \mathrm{OC}$ & Humic Organic Cryosol \\
\hline TEI.OC & Terric Fibric Organic Cryosol \\
\hline TME . OC & Terric Mesic Organic Cryosol \\
\hline THU. OC & Terric Humic Organic Cryosol \\
\hline GC. OC & Glacic Organic Cryosol \\
\hline O. HG & Orthic Humic Gleysol \\
\hline R. HG & Rego Humic Gleysol \\
\hline FE.HG & Fera Humic Gleysol \\
\hline SZ.HG & Solonetzic Humic Gleysol \\
\hline $0 . G$ & Orthic Gleysol \\
\hline R.G & Rego Gleysol \\
\hline $\mathrm{FE} \cdot \mathrm{G}$ & Fera Gleysol \\
\hline SZ.G & Solonetzic Gleysol \\
\hline O. LG & Orthic Luvic Gleysol \\
\hline $\mathrm{HU} \cdot \mathrm{LG}$ & Humic Luvic Gleysol \\
\hline FE. LG & Fera Luvic Gleysol \\
\hline FR. LG & Fragic Luvic Gleysol \\
\hline SZ . LG & Solonetzic Luvic Gleysol \\
\hline O.GBL & Orthic Gray Brown Luvisol \\
\hline BR. GBL & Brunisolic Gray Brown Luvisol \\
\hline PZ . GBL & Podzolic Gray Brown Luvisol \\
\hline GL . GBL & Gleyed Gray Brown Luvisol \\
\hline GLBR . GBL & Gleyed Brunisolic Gray Brown Luvisol \\
\hline GLPZ . GBL & Gleyed Podzolic Gray Brown Luvisol \\
\hline
\end{tabular}




\begin{tabular}{|c|c|}
\hline $0 . \mathrm{GL}$ & Orthic Gray Luvisol \\
\hline D. GL & Dark Gray Luvisol \\
\hline BR.GL & Brunisolic Gray Luvisol \\
\hline PZ.GL & Podzolic Gray Luvisol \\
\hline SZ .GL & Solonetzic Gray Luvisol \\
\hline FR.GL & Fragic Gray Luvisol \\
\hline GL . GL & Gleyed Gray Luvisol \\
\hline GLD . GL & Gleyed Dark Gray Luvisol \\
\hline GLBR . GL & Gleyed Brunisolic Gray Luvisol \\
\hline GLPZ . GL & Gleyed Podzolic Gray Luvisol \\
\hline GLSZ . GL & Gleyed Solonetzic Gray Luvisol \\
\hline GLFR.GL & Gleyed Fragic Gray Luvisol \\
\hline TY.F & Typic Fibrisol \\
\hline $\mathrm{ME} . \mathrm{F}$ & Mesic Fibrisol \\
\hline $\mathrm{HU} . \mathrm{F}$ & Humic Fibrisol \\
\hline $\mathrm{LM} \cdot \mathrm{F}$ & Limno Fibrisol \\
\hline$C U \cdot F$ & Cumulo Fibrisol \\
\hline T.F & Terric Fibrisol \\
\hline $\mathrm{TME} \cdot \mathrm{F}$ & Terric Mesic Fibrisol \\
\hline THU. $\mathrm{F}$ & Terric Humic Fibrisol \\
\hline$H Y . F$ & Hydric Fibrisol \\
\hline TY.M & Typic Mesisol \\
\hline FI.M & Fibric Mesisol \\
\hline HU . M & Humic Mesisol \\
\hline LM. M & Limno Mesisol \\
\hline $\mathrm{CU} \cdot \mathrm{M}$ & Cumulo Mesisol \\
\hline $\mathrm{T} \cdot \mathrm{M}$ & Terric Mesisol \\
\hline TFI.M & Terric Fibric Mesisol \\
\hline THU . M & Terric Humic Mesisol \\
\hline HY . M & Hydric Mesisol \\
\hline TY.H & Typic Humisol \\
\hline $\mathrm{FI} \cdot \mathrm{H}$ & Fibric Humisol \\
\hline $\mathrm{ME} \cdot \mathrm{H}$ & Mesic Humisol \\
\hline $\mathrm{LM} \cdot \mathrm{H}$ & Limno Humisol \\
\hline $\mathrm{CU} \cdot \mathrm{H}$ & Cumulo Humisol \\
\hline $\mathrm{T} \cdot \mathrm{H}$ & Terric Humisol \\
\hline TEI.H & Terric Fibric Humisol \\
\hline $\mathrm{TME} \cdot \mathrm{H}$ & Terric Mesic Humisol \\
\hline $\mathrm{HY} \cdot \mathrm{H}$ & Hydric Humisol \\
\hline $\mathrm{HE} . \mathrm{FO}$ & Hemic Folisol \\
\hline $\mathrm{HI} . \mathrm{FO}$ & Histic Folisol \\
\hline $\mathrm{HU} \cdot \mathrm{FO}$ & Humic Folisol \\
\hline LI. FO & Lignic Folisol \\
\hline $\mathrm{O} . \mathrm{HP}$ & Orthic Humic Podzol \\
\hline $\mathrm{OT} \cdot \mathrm{HP}$ & Ortstein Humic Podzol \\
\hline P. HP & Placic Humic Podzol \\
\hline $\mathrm{DU} . \mathrm{HP}$ & Duric Humic Podzol \\
\hline FR. HP & Fragic Humic Podzol \\
\hline O.FHP & Orthic Ferro-Humic Podzol \\
\hline OT.FHP & Ortstein Ferro-Humic Podzol \\
\hline P.FHP & Placic Ferro-Humic Podzol \\
\hline DU . FHP & Duric Ferro-Humic Podzol \\
\hline FR.FHP & Fragic Ferro-Humic Podzol \\
\hline LU . FHP & Luvisolic Ferro-Humic Podzol \\
\hline
\end{tabular}

Page 12 


\begin{tabular}{|c|c|}
\hline SM. FHP & Sombric Ferro-Humic Podzol \\
\hline GL . FHP & Gleyed Ferro-Humic Podzol \\
\hline GLSM . FHP & Gleyed Sombric Ferro-Humic Podzol \\
\hline GLOT . FHP & Gleyed Ortstein Ferro-Humic Podzol \\
\hline O. HFP & Orthic Humo-Ferric Podzol \\
\hline OT. HFP & Ortstein Humo-Ferric Podzol \\
\hline P. HFP & Placic Humo-Ferric Podzol \\
\hline DU. HFP & Duric Humo-Ferric Podzol \\
\hline FR. HFP & Fragic Humo-Ferric Podzol \\
\hline LU . HFP & Luvisolic Humo-Ferric Podzol \\
\hline GL . HFP & Gleyed Humo-Ferric Podzol \\
\hline GLSM . HFP & Gleyed Sombric Humo-Ferric Podzol \\
\hline $\mathrm{SM} \cdot \mathrm{HFP}$ & Sombric Humo-Ferric Podzol \\
\hline GLOT . HFP & Gleyed Ortstein Humo-Ferric Podzol \\
\hline$O \cdot R$ & Orthic Regosol \\
\hline $\mathrm{CU} \cdot \mathrm{R}$ & Cumulic Regosol \\
\hline $\mathrm{GL} \cdot \mathrm{R}$ & Gleyed Regosol \\
\hline GLCU . R & Gleyed Cumulic Regosol \\
\hline O. HR & Orthic Humic Regosol \\
\hline $\mathrm{CU} \cdot \mathrm{HR}$ & Cumulic Humic Regosol \\
\hline GL . HR & Gleyed Humic Regosol \\
\hline GLCU . HR & Gleyed Cumulic Humic Regosol \\
\hline B.SZ & Brown solonetz \\
\hline DB. SZ & Dark Brown Solonetz \\
\hline BL . SZ & Black Solonetz \\
\hline A.SZ & Alkaline Solonetz \\
\hline GLB . SZ & Gleyed Brown solonetz \\
\hline GLDB.SZ & Gleyed Dark Brown Solonetz \\
\hline GLBL . SZ & Gleyed Black Solonetz \\
\hline B.SS & Brown solodized solonetz \\
\hline DB.SS & Dark Brown Solodized Solonetz \\
\hline BL . SS & Black Solodized Solonetz \\
\hline DG.SS & Dark Gray Solodized Solonetz \\
\hline G.SS & Gray Solodized Solonetz \\
\hline GLB. SS & Gleyed Brown Solodized Solonetz \\
\hline GLDB . SS & Gleyed Dark Brown Solodized Solonetz \\
\hline GLBL . SS & Gleyed Black Solodized Solonetz \\
\hline GLDG . SS & Gleyed Dark Gray Solodized Solonetz \\
\hline GLG . SS & Gleyed Gray Solodized Solonetz \\
\hline B. SO & Brown solod \\
\hline DB. SO & Dark Brown Solod \\
\hline BL . SO & Black Solod \\
\hline DG.SO & Dark Gray Solod \\
\hline G. SO & Gray solod \\
\hline GLB . SO & Gleyed Brown solod \\
\hline GLDB . SO & Gleyed Dark Brown Solod \\
\hline GLBL . SO & Gleyed Black Solod \\
\hline GLDG . SO & Gleyed Dark Gray Solod \\
\hline GLG . SO & Gleyed Gray solod \\
\hline PROF ILE & Header from Detail II file (Unknown) \\
\hline DATE & YY.MM.DD Date of last revision \\
\hline $\mathrm{A}-\mathrm{THICK}$ & Thickness of A horizon \\
\hline & L20 less than 20 \\
\hline
\end{tabular}

Page 13 


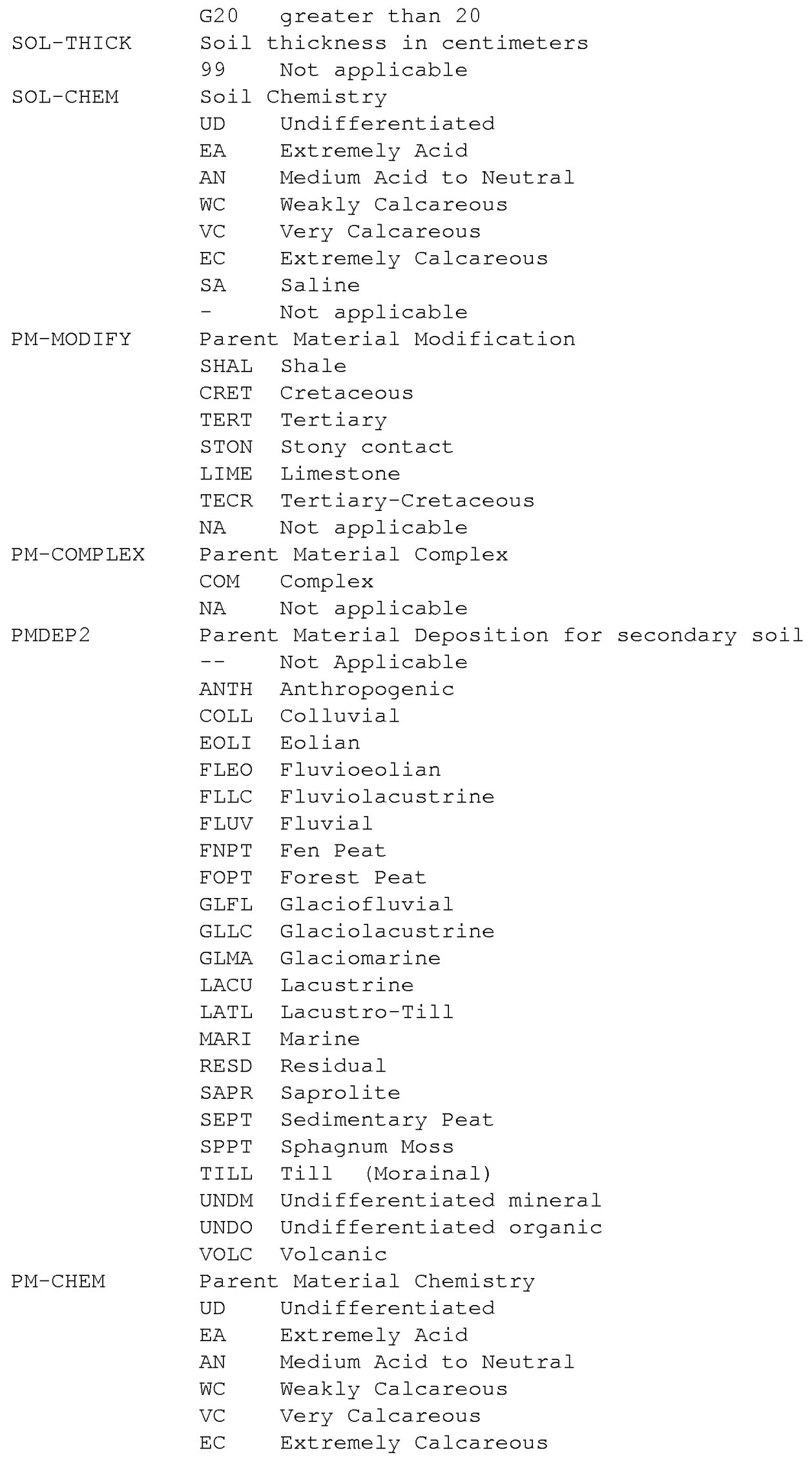

Page 14 


\begin{tabular}{|c|c|c|}
\hline \multirow[b]{3}{*}{ PMTEXCLASS } & SA & Saline \\
\hline & - & Not applicable \\
\hline & \multicolumn{2}{|c|}{ Parent Material Textural Class } \\
\hline & \multicolumn{2}{|c|}{$\begin{array}{l}\text { Parent Materlal Textural class } \\
\text { VCS very coarse sand }\end{array}$} \\
\hline & CS & coarse sand \\
\hline & LCS & loamy coarse sand \\
\hline & S & sand \\
\hline & F S & fine sand \\
\hline & LS & loamy sand \\
\hline & LFS & loamy fine sand \\
\hline & VFS & very fine sand \\
\hline & LVFS & loamy very fine sand \\
\hline & CSL & coarse sandy loam \\
\hline & SL & sandy loam \\
\hline & FSL & fine sandy loam \\
\hline & VFSL & very fine sandy loam \\
\hline & $\mathrm{L}$ & loam \\
\hline & SIL & silt loam \\
\hline & SCL & sandy clay loam \\
\hline & SICL & silty clay loam \\
\hline & CL & clay loam \\
\hline & $\mathrm{C}$ & clay \\
\hline & $\mathrm{HC}$ & heavy clay \\
\hline & 0 & organic \\
\hline & $\mathrm{F}$ & fibric \\
\hline & $\mathrm{M}$ & mesic \\
\hline & $\mathrm{H}$ & humic \\
\hline & NA & not applicable \\
\hline TEXMODIFY & Textur & ce Modifier \\
\hline & $\mathrm{GR}$ & gravelly \\
\hline & VG & very gravelly \\
\hline & WY & woody \\
\hline & NA & not applicable \\
\hline FAMPARTSIZ & Famil & Particle Size \\
\hline & UD & undifferentiated \\
\hline & $\mathrm{FR}$ & fragmental \\
\hline & SK & skeletal \\
\hline & SY & sandy \\
\hline & CL & coarse loamy \\
\hline & $\mathrm{FL}$ & fine loamy \\
\hline & LY & loamy \\
\hline & CY & clayey \\
\hline & SM & stratified mineral \\
\hline & SU & stratified mineral and organic \\
\hline & so & stratified organic \\
\hline & OG & organic \\
\hline & WY & woody \\
\hline & FI & fibric \\
\hline & $\mathrm{ME}$ & mesic \\
\hline & $\mathrm{HU}$ & humic \\
\hline & $\mathrm{RU}$ & bedrock undifferentiated \\
\hline & $\mathrm{RA}$ & bedrock acid \\
\hline & $\mathrm{RB}$ & bedrock basic \\
\hline & RS & bedrock soft \\
\hline
\end{tabular}

Page 15 


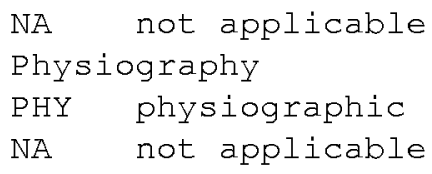

\subsubsection{Compressed CD-ROM Files}

On the BOREAS CD-ROMs, files 1, 11, and 12 listed above are stored as ASCII text files; however, files 2 - 10 have been compressed with the Gzip compression program (file name *.gz). These data have been compressed using gzip version 1.2.4 and the high compression (-9) option (Copyright (C) 1992-1993 Jean-loup Gailly). Gzip (GNU zip) uses the Lempel-Ziv algorithm (Welch, 1994) used in the zip and PKZIP programs. The compressed files may be uncompressed using gzip (-d option) or gunzip. Gzip is available from many Web sites (for example, ftp site prep.ai.mit.edu/pub/gnu/gzip-**) for a variety of operating systems in both executable and source code form. Versions of the decompression software for various systems are included on the CD-ROMs.

\section{Data Manipulations}

\subsection{Formulae}

\subsubsection{Derivation Techniques and Algorithms}

The GIS software package ARC/INFO (Version 6 and 7) was used to grid these data.

\subsection{Data Processing Sequence}

\subsubsection{Processing Steps}

- Seven separate vector ARC/INFO coverages were edgematched to make the edges of the various coverages match up as much as possible.

- The soil code or modifier (depending on what was being gridded) was linked to a table of numeric values to assign a number to each polygon based on the soil code or modifier of the polygon.

- These edgematched vector data were then gridded by assigning a numeric value to each pixel.

- $\quad$ BOREAS Information System (BORIS) staff copied the ASCII and compressed the binary files for release on CD-ROM.

\subsubsection{Processing Changes}

None.

\subsection{Calculations}

None.

\subsubsection{Special Corrections/Adjustments}

None.

\subsubsection{Calculated Variables}

None.

\subsection{Graphs and Plots}

None. 


\section{Errors}

\subsection{Sources of Error}

A major source of error in the original data set could be digitizing error. There is also the possibility of coding errors in the attributes. The value of an attribute could have been keyed in incorrectly.

There is some question about the positional accuracy of the data. Although the data are mapped at a scale of 1:125,000, the source of the mapping is aerial photography that was not orthocorrected. Therefore, the soils mapping may contain distortions that exist in the air photos. This problem can be mitigated by "rubber sheeting" the data to an accurate map base, or acquiring the original air photos and compensating for their distortions. However, the minor benefits of improved positional accuracy would not be worth the time and effort of correcting all of these data.

The data that were gridded comprised seven vector layers that were edgematched. Although most of the attributes of polygons along the seams are the same, in some cases the soil attributes are different. This can cause some discontinuities in these layers.

\subsection{Quality Assessment}

\subsubsection{Data Validation by Source Unknown.}

\subsubsection{Confidence Level/Accuracy Judgment}

Although the gridding procedure itself is highly accurate, there is some question as to the positional accuracy of the original data. Therefore, caution should be used when inferring information from this data set.

The source in Canada from whom these data were received has strong caveats about the use of the data. These data are constantly being updated as new data are collected and become available. These data represent broad generalizations about the soil characteristics of this area. Caution is to be used when inferring information from the data.

\subsubsection{Measurement Error for Parameters Unknown.}

\subsubsection{Additional Quality Assessments Unknown.}

\subsubsection{Data Verification by Data Center}

Each gridded image was spot-checked to ensure that the gridding procedure assigned a digital number $(\mathrm{DN})$ to each attribute value.

\section{Notes}

\subsection{Limitations of the Data}

The original data were received in seven parts. These seven parts were edgematched so that the polygon boundaries were aligned with each other. The gridded data represent a merging of these two data sets. Unfortunately, some of the attributes of polygons along the border have different values. Therefore, a sharp discontinuity may exist along a map edge in the images.

\subsection{Known Problems with the Data}

The original vector data apparently were digitized from aerial photography that was not orthometrically corrected. Therefore, the locational accuracy of the soil polygons may not be very accurate. 


\subsection{Usage Guidance}

Users of these data should be cautious about inferring information from this data set and extending those inferences over a larger area. The polygons from the original data set are large and may have small inclusions of various soil types that are not mapped in these data layers.

Before uncompressing the Gzip files on CD-ROM, be sure that you have enough disk space to hold the uncompressed data files. Then use the appropriate decompression program provided on the CD-ROM for your specific system.

\subsection{Other Relevant Information}

None.

\section{Application of the Data Set}

The original intended use of these data is unknown. Users from the BOREAS project might use these data for hydrological modeling or some other ecosystem modeling activity.

\section{Future Modifications and Plans}

None.

\section{Software}

\subsection{Software Description}

The GIS software package ARC/INFO (Version 6 and 7) was used to grid these data. Gzip (GNU zip) uses the Lempel-Ziv algorithm (Welch, 1994) used in the zip and PKZIP commands.

\subsection{Software Access}

ARC/INFO is a proprietary software package produced by Environmental Systems Research Institute, Inc. (ESRI), Redlands, CA.

Gzip is available from many Web sites across the Internet (for example) ftp site prep.ai.mit.edu/pub/gnu/gzip-**) for a variety of operating systems in both executable and source code form. Versions of the decompression software for various systems are included on the CD-ROMs.

\section{Data Access}

The BOREAS soils data over the SSA in raster format and AEAC projection are available from the Earth Observing System Data and Information System (EOSDIS) Oak Ridge National Laboratory (ORNL) Distributed Active Archive Center (DAAC). 


\subsection{Contact Information}

For BOREAS data and documentation please contact:

ORNL DAAC User Services

Oak Ridge National Laboratory

P.O. Box 2008 MS-6407

Oak Ridge, TN 37831-6407

Phone: (423) 241-3952

Fax: (423) 574-4665

E-mail: ornldaac@ornl.gov or ornl@eos.nasa.gov

\subsection{Data Center Identification}

Earth Observing System Data and Information System (EOSDIS) Oak Ridge National Laboratory (ORNL) Distributed Active Archive Center (DAAC) for Biogeochemical Dynamics http://www-eosdis.ornl.gov/.

\subsection{Procedures for Obtaining Data}

Users may obtain data directly through the ORNL DAAC online search and order system [http://www-eosdis.ornl.gov/] and the anonymous FTP site [ftp://www-eosdis.ornl.gov/data/] or by contacting User Services by electronic mail, telephone, fax, letter, or personal visit using the contact information in Section 15.1.

\subsection{Data Center Status/Plans}

The ORNL DAAC is the primary source for BOREAS field measurement, image, GIS, and hardcopy data products. The BOREAS CD-ROM and data referenced or listed in inventories on the CD-ROM are available from the ORNL DAAC.

\section{Output Products and Availability}

\subsection{Tape Products}

These data can be made available on 8-mm, Digital Archive Tape (DAT), or 9-track tapes at 1600 or 6250 Bytes Per Inch (BPI).

\subsection{Film Products}

None.

\subsection{Other Products}

These data are available on the BOREAS CD-ROM series.

\section{References}

\subsection{Platform/Sensor/Instrument/Data Processing Documentation}

Welch, T.A. 1984. A Technique for High Performance Data Compression. IEEE Computer, Vol. 17, No. 6, pp. 8-19.

\subsection{Journal Articles and Study Reports}

Acton, D.F., G.A. Padbury, and J.A. Shields. 1991. Soil Landscapes of Canada-Saskatchewan Digital Map Data; Scale 1:1000000; CanSIS No. SK018200, Version 90.11.30; CLBRR Archive, Agriculture Canada, Research Branch, Ottawa, Canada (CLBRR Contribution No. 91-107D). 
Newcomer, J., D. Landis, S. Conrad, S. Curd, K. Huemmrich, D. Knapp, A. Morrell, J. Nickeson, A. Papagno, D. Rinker, R. Strub, T. Twine, F. Hall, and P. Sellers, eds. 2000. Collected Data of The Boreal Ecosystem-Atmosphere Study. NASA. CD-ROM.

Padbury, G.A., and J.A. Shields. 1991. Soil Landscapes of Canada-Saskatchewan Soil Landscapes Polygon Attribute Digital Data. CanSIS No. SK018200, version 90.11.30; CLBRR Archive, Agriculture Canada, Research Branch, Ottawa, Canada. (CLBRR Contribution No. 91-108D).

Sellers, P. and F. Hall. 1994. Boreal Ecosystem-Atmosphere Study: Experiment Plan. Version 1994-3.0, NASA BOREAS Report (EXPLAN 94).

Sellers, P. and F. Hall. 1996. Boreal Ecosystem-Atmosphere Study: Experiment Plan. Version 1996-2.0, NASA BOREAS Report (EXPLAN 96).

Sellers, P., F. Hall, and K.F. Huemmrich. 1996. Boreal Ecosystem-Atmosphere Study: 1994 Operations. NASA BOREAS Report (OPS DOC 94).

Sellers, P., F. Hall, and K.F. Huemmrich. 1997. Boreal Ecosystem-Atmosphere Study: 1996 Operations. NASA BOREAS Report (OPS DOC 96).

Sellers, P., F. Hall, H. Margolis, B. Kelly, D. Baldocchi, G. den Hartog, J. Cihlar, M.G. Ryan, B. Goodison, P. Crill, K.J. Ranson, D. Lettenmaier, and D.E. Wickland. 1995. The boreal ecosystem-atmosphere study (BOREAS): an overview and early results from the 1994 field year. Bulletin of the American Meteorological Society. 76(9):1549-1577.

Sellers, P.J., F.G. Hall, R.D. Kelly, A. Black, D. Baldocchi, J. Berry, M. Ryan, K.J. Ranson, P.M. Crill, D.P. Lettenmaier, H. Margolis, J. Cihlar, J. Newcomer, D. Fitzjarrald, P.G. Jarvis, S.T. Gower, D. Halliwell, D. Williams, B. Goodison, D.E. Wickland, and F.E. Guertin. 1997. BOREAS in 1997: Experiment Overview, Scientific Results and Future Directions. Journal of Geophysical Research 102 (D24): 28,731-28,770.

\subsection{Archive/DBMS Usage Documentation}

None.

\section{Glossary of Terms}

None.

\section{List of Acronyms}

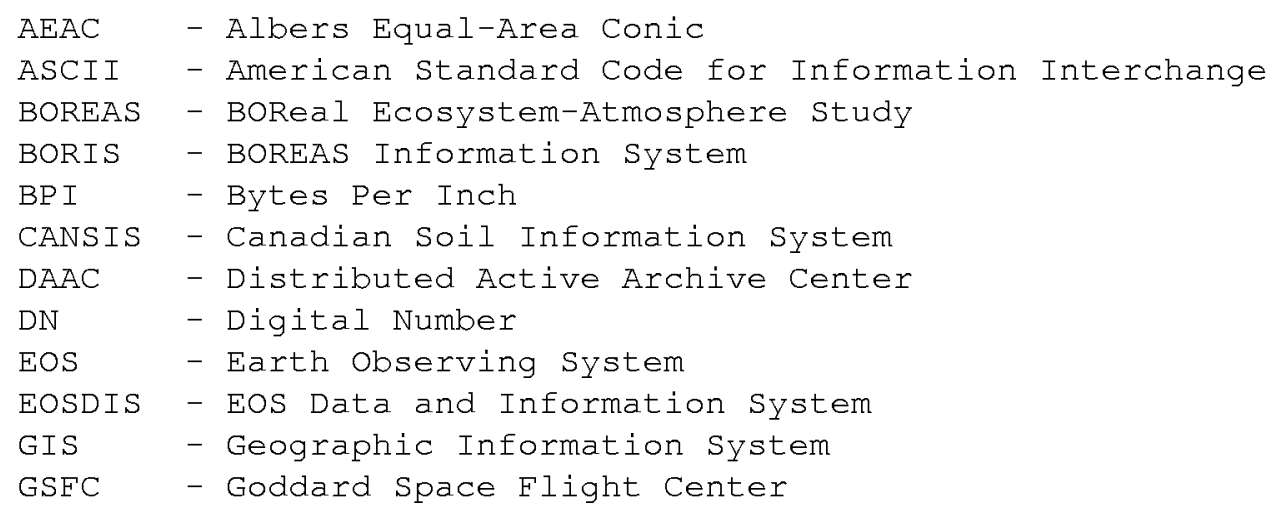




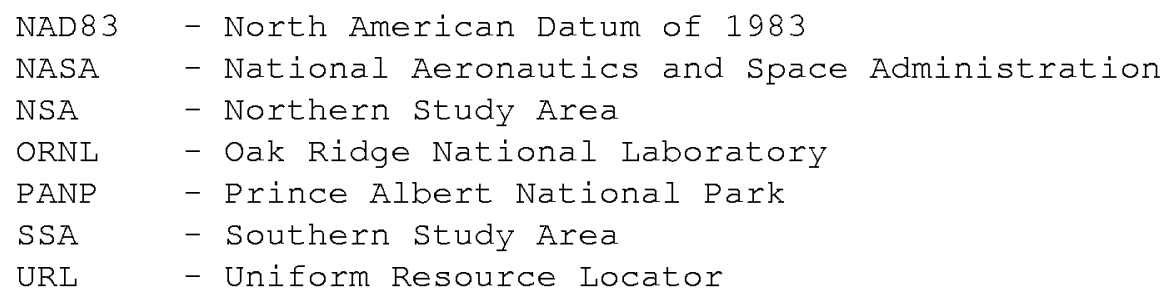

\section{Document Information}

\subsection{Document Revision Dates}

Written: 02-Dec-1994

Last Updated: 29-Nov-1999

\subsection{Document Review Dates}

BORIS Review: 20-Jun-1997

Science Review:

\subsection{Document ID}

\subsection{Citation}

When using these data, please include the following acknowledgment as well as citations of relevant papers in Section 17.2:

The author(s) express their thanks to Dr. Harold Rostad (Agriculture Canada) for providing the original vector data to the BOREAS Information System (BORIS) and to the BORIS staff for creating and documenting the raster product.

If using data from the BOREAS CD-ROM series, also reference the data as:

BOREAS Staff Science, "BOREAS Staff Science GIS Data Collection Program." In Collected Data of The Boreal Ecosystem-Atmosphere Study. Eds. J. Newcomer, D. Landis, S. Conrad, S. Curd, K. Huemmrich, D. Knapp, A. Morrell, J. Nickeson, A. Papagno, D. Rinker, R. Strub, T. Twine, F. Hall, and P. Sellers. CD-ROM. NASA, 2000.

Also, cite the BOREAS CD-ROM set as:

Newcomer, J., D. Landis, S. Conrad, S. Curd, K. Huemmrich, D. Knapp, A. Morrell, J. Nickeson, A. Papagno, D. Rinker, R. Strub, T. Twine, F. Hall, and P. Sellers, eds. Collected Data of The Boreal Ecosystem-Atmosphere Study. CD-ROM. NASA, 2000.

\subsection{Document Curator}

\subsection{Document URL}


Public reporting burden for this collection of information is estimated to average 1 hour per response, including the time for reviewing instructions, searching existing data sources, gathering and maintaining the data needed and completing and reviewing the collection of information. Send comments regarding this burden estimate or any other aspect of this collection of information including suggestions for reducing this burden, to Washington Headquarters Services, Directorate for Information Operations and Reports, 1215 Jefferson Davis Highway, Suite 1204, Arlington, VA 22202-4302, and to the Office of Management and Budget, Paperwork Reduction Project (0704-0188), Washington, DC 20503.

\begin{tabular}{|l|l|l|}
\hline 1. AGENCY USE ONLY (Leave blank) & 2. REPORT DATE & 3. REPORT TYPE AND DATES COVERED
\end{tabular}

4. TITLE AND SUBTITLE

September 2000

Technical Memorandum

Technical Report Series on the Boreal Ecosystem-Atmosphere Study (BOREAS) BOREAS Soils Data over the SSA in Raster Format and AEAC Projection

\section{AUTHOR(S)}

David Knapp and Harold Rostad

Forrest G. Hall, Editor

\section{PERFORMING ORGANIZATION NAME(S) AND ADDRESS (ES)}

Goddard Space Flight Center

Greenbelt, Maryland 20771

5. FUNDING NUMBERS

\section{3}

RTOP: 923-462-33-01
9. SPONSORING / MONITORING AGENCY NAME(S) AND ADDRESS (ES)

National Aeronautics and Space Administration

Washington, DC 20546-0001
8. PEFORMING ORGANIZATION

2000-03136-0

\section{SUPPLEMENTARY NOTES}

D. Knapp: Raytheon ITSS, NASA Goddard Space Flight Center, Greenbelt, Maryland;

H. Rostad: Agriculture Canada, Ottawa, Ontario, Canada;

\begin{tabular}{l|l}
\hline 12a. DISTRIBUTION / AVAILABILITY STATEMENT & 12b. DISTRIBUTION CODE \\
Unclassified-Unlimited & \\
Subject Category: 43 & \\
Report available from the NASA Center for AeroSpace Information, \\
7121 Standard Drive, Hanover, MD 21076-1320. (301) $621-0390$.
\end{tabular}

13. ABSTRACT (Maximum 200 words)

This data set consists of GIS layers that describe the soils of the BOREAS SSA. The original data were submitted as vector layers that were gridded by BOREAS staff to a 30-meter pixel size in the AEAC projection. These data layers include the soil code (which relates to the soil name), modifier (which also relates to the soil name), and extent (indicating the extent that this soil exists within the polygon). There are three sets of these layers representing the primary, secondary, and tertiary soil characteristics. Thus, there is a total of nine layers in this data set along with supporting files. The data are stored in binary, image format files.

\author{
14. SUBJECT TERMS \\ BOREAS, remote sensing science, AEAC projection.
}

10. SPONSORING / MONITORING AGENCY REPORT NUMBER

Vol. 115

\begin{tabular}{l|l|} 
& \\
\hline 17. SECURITY CLASSIFICATION & 18. SECURITY CLASSIFICATION \\
OF REPORT & OF THIS PAGE \\
Unclassified & Unclassified \\
\hline
\end{tabular}

19. SECURITY CLASSIFICATION OF ABSTRACT

Unclassified
15. NUMBER OF PAGES

21

16. PRICE CODE
20. LIMITATION OF ABSTRACT

UL 
